\title{
The Sri Lankan Undergraduate in the Sinhala Press
}

\author{
Kaushalya Perera \\ Department of English, Faculty of Arts \\ University of Colombo, Sri Lanka \\ kaushalya@english.cmb.ac.lk
}

\begin{abstract}
The problems, protests and politics of the state university system are constantly featured in Sri Lankan media. While researchers have shown systemic reasons for violence in universities (Weeramunda, 2008; Samaranayake, 2015), public perception of undergraduates, as shown in the media, appears to construe students as needlessly rebellious and in perpetual protest. With the understanding that the media representation of a group is an important part of public discourse, this paper aims to conduct a qualitative analysis of the Sri Lankan undergraduate as shown in selected newspapers from the Sinhala press. Editorials, feature articles and news reports in Sinhala newspapers (both state-owned and privatelyowned) from an eventful week in January 2012 are studied closely. A secondary aim is to identify linguistic structures used for stance-taking in Sinhala media discourse. The findings show a significant difference in the representation of undergraduates between these two types of newspapers, with the state-controlled newspapers covering undergraduate issues less whilst at the same time portraying them in a polarised manner (as victims or agents of aggression). Privately-owned newspapers provide more coverage of student issues, often incorporating student voices and explicitly showing their support of student causes. In terms of language structures, analysis shows that the discourse of the Sinhala press incorporates linguistic features such as metaphors, focused clauses, double negation, and subject deletion for stance-marking. Overall, this paper illustrates divergent public discourses on undergraduates present in Sinhala media.
\end{abstract}

Keywords: Sri Lankan undergraduates, student violence, stance-marking, Sinhala media, discourse 


\section{Introduction}

The problems, protests and politics of the state university system are constantly featured in Sri Lankan media. Student politics are a particularly frequent topic in print media, which is still the most widely accessible channel of information for the Sri Lankan public. Analysing the representation of Sri Lankan Tamil refugees in Dutch newspapers in the 1980s, Teun van Dijk (1988) contended that the study of dominant ideologies reproduced by media needs deeper semantic analyses than those provided by quantitative oriented content analysis. Following this tenet, this paper discusses the representation of the undergraduate of state universities in the Sinhala press of Sri Lanka.

News discourse is defined by John E. Richardson (2007) as "the system (and the values upon which it is based) whereby news organisations select and organise the possible statements on a particular subject” (p.76). Bednarek \& Caple (2014) state that newsworthiness is decided by reason of such factors as "Proximity (geographical or cultural 'nearness'); Negativity (negative aspects, e.g. conflict, death, disaster, accidents, negative consequences); Eliteness (elite status); and Superlativeness ('the more X, the more newsworthy')" (p.136) and go on to say that it is "existing in and constructed through discourse" (p.137, emphasis in original). As such, news is embedded in broader discourses present in society at the time, being formed by them even as it influences such discourses. Of special significance to this paper are studies of news or media discourses on social movements and minority populations. Van Dijk's (1991) analysis of Dutch newspapers in the 1980s is an illuminating illustration of how the influx of Tamil refugees to Netherlands (and other parts of Europe) at the time was constructed by the press and the political elite as a 'problem' and used later by conservative political elements to continue anti-immigration policies. The selection and portrayal of events and actors in the press then is not an accidental or random happening but part of larger discourses at work in society.

In contrast to constant and intense attention to 'student unrest,' in the Sri Lankan press, scholarly attention on undergraduate violence has been sporadic (Samaranayake, 1992; Weeramunda, 2008; Zubair, 2011; Schubert, 2012). In 
Ralph Pieris' (1964) article 'Universities, politics and public opinion in Ceylon', Pieris discusses public opinion of universities, but there is no mention of student politics. Gamini Samaranayake (1992), using the University of Peradeniya as a case in point, ties student unrest to "the changing socio-economic background of the students and the prevailing political atmosphere in Sri Lanka" (p.112, see also Samaranayake 2015; Samaranayake 1999). In contrast, A. J. Weeramunda (2008), in a report on university violence funded by the World Bank and commissioned by the National Education Commission, argued that student violence and indiscipline "have been occasioned by a variety of deficiencies in the administrative, academic, and managerial aspects of the university system" and need multiple solutions including "reductions of [the] government's role to providing of funds" (p.6).

The focus on student violence as a dominant theme in scholarship on universities is understandable given the high levels of violence taking place within universities. However, this also highlights a gap in our knowledge on other aspects of this complex issue. The link between student violence and reductions in state funding to universities in particular, illustrates a prevalent discourse on higher education that needs further research that moves beyond the rather straightforward correlations that are currently drawn between these factors. Given the importance of student activism to university issues, the lack of research in this area is a significant gap.

Methodologically, analyses of student violence take the form of situational overviews (Uswatte-Aratchi, 1974; Samaranayake, 2015, 2016), or narrativebased studies (Pieris, 1964; Schubert, 2012). Apparent from this admittedly brief survey is the lack of empirical research on student politics, especially from anthropological or sociological studies, and the predominant framing of student issues, even within scholarship and academia, from the perspective of violence. Academic discourses being embedded in wider social discourses, and the equation of student issues with student violence needs to be critiqued, at the same time that we, as academics, need to position and work towards violence free universities. 
The paper begins with a brief review of recent events relating to undergraduates in state universities. After a summary of the design and method of study, it proceeds to the analyses of state-controlled newspapers and thereafter, privatelyowned newspapers.

\section{Context}

A full description of shifts in the public perception of undergraduates in postcolonial history would need a longitudinal study. Still, some insight to public perception may be gained from literature that academics have produced. In the 1960s, the "Chronicle" section of the international journal Minerva published two reports on the state of higher education in 'Ceylon', as part of a regular series on global incidents ('Chronicle', 1966; 'Chronicle', 1969). It is apparent that by this time, undergraduates were already protesting against a lack of facilities and problematic administrative behaviours (e.g. related to admission of undergraduates). A report was commissioned and the Minister of Education personally intervened in the situation ('Chronicle', 1966). The demands for adequate facilities for larger numbers of students then appears to be a persistent issue which is still part of student demands. With their involvement in the 1971 insurrection, students were associated with revolutionary movements and national politics (a less significant issue in the 1960s). Since then, universities were seen to be 'hotspots' of political activity (Uyangoda, 1989; Wickramasinghe, 2005). By the 1990s, undergraduates were in the news for continuous protests, marches, and strikes, an illustration of their involvement in political movements of the country. A. J. Weeramunda's (2008) commissioned study on 'violence' and 'indiscipline' can be read as an indicator of public perception that universities were sites of violence. Weeramunda lists multiple reasons for violence in universities (including but not limited to student protests) and links it to a number of underlying issues including low quality of teaching, involvement of national political parties in student politics, lack of university autonomy, and successive governments' inability to deal successfully with graduate unemployment - many of these echoing the Wijesekera Report in 1965 ('Chronicle', 1966; also see Samaranayake 2016). 
Student unrest has periodically and consistently been linked to economic lethargy and the high levels of graduate unemployment in the periods leading up to JVP uprisings (Samaranayake 2016; 1997). Since the 1970s, undergraduates have also protested against national issues such as militarization, free education and privatization, showing an increased regard for issues that impinge on education. These nuances of student politics, however, are generally not seen in media discourses of undergraduate politics or in public discourses on students in universities.

Since 2010, universities have featured in public discourse significantly more, due to several reasons I summarize in this section. First, undue state intervention in university administration has increased, to the extent that it has been described as “unprecedented" by the university teachers' trade union (FUTA 2013 May 07). During 2011-2012, the then government tried to introduce three interventions: a) the 'Leadership Course,' a mandatory orientation course for incoming undergraduates conducted by the Sri Lanka Armed Forces in military institutions (starting in 2011); b) the proposal to enact the Quality Assurance Accreditation and Qualification Framework bill, or 'Private Universities Bill' (in 2011); and c) the security services of Rakna Lanka Pvt (Ltd) which the universities were forced to hire (again 2011). Only the enactment of the private universities bill was averted, after a few months of agitation by the public, including by undergraduates. The Federation of University Teachers' Associations (FUTA) launched its own wage campaign in 2010 and a more dynamic strike campaign in 2012.

January 2012, the month discussed in this paper, was particularly eventful. The government had stated their intent to pass the Private Universities Bill in Parliament in January, which resulted in wide spread protests by both undergraduates and academics during this month (Tennakoon \& Kasthuri, 2012). During the first week of January, an iconic statue in the University of Sri Jayewardenepura was bombed (by armed forces according to students and by students according to the authorities) (Dasanayaka, 2012). Students led a protest march heading to Temple Trees. At least two universities (Universities of 
Kelaniya and Rajarata) had suspended students allegedly on charges of ragging, against which undergraduates of both universities marched in protest (Kasthuri \& Kumara, 2012). Rajarata University students also petitioned the Human Rights Commission against the university administration, citing as grievances the closure of the university, uninvestigated suspensions, and the lack of clinical training facilities for medical students stalling their graduation. Meanwhile, some students of the same university's Faculty of Medicine were suspended for two years over an incident that took place in 2011 (Samarathunga, Jayaruk \& Perera, 2012). During this same month, in Sabaragamuwa University unidentified men attacked four students; while some students of the same university damaged the house of a student counselor. At the University of Ruhuna undergraduates had an altercation with the Police who prevented them from going on a protest march against the Private Universities Bill (Samarathunga et al, 2012).

As we can see, the avid scrutiny of universities by the media during January 2012 was not unwarranted as per principles of newsworthiness, particularly negativity and superlativeness (Bednarek and Caple, 2014). What I aim to show, however, is that the nature of media discourse was simplistic in some instances, and fed into stereotypes of undergraduates, though some variation occurs in terms of newspaper ownership.

\section{Methodology}

This study is a discourse analysis of the representation of Sri Lankan undergraduates in Sinhala print media, using four Sinhala language newspapers. It is not a quantitative analysis of items, but a thematic analysis focusing on the reporting of events related to universities during an eventful week in January 2012 (see above).

The choice of Sinhala newspapers was based on coverage and attentiveness to the topic. Sinhala newspapers have wider national coverage than Tamil or English newspapers. Secondly, Sinhala newspapers had a higher number of items on universities in comparison to English newspapers. ${ }^{i}$ A second aim is to contribute to studies on discourse in Sinhala. 
The newspapers selected for analysis were Silumina, Dinamina, Irida Lankadeepa, and Lankadeepa. These newspapers were selected based on the criteria of a) ownership, b) day of publication, and c) rate of circulation. Silumina and Dinamina are published by the state-administered Associated Newspapers of Ceylon Ltd (also known as the 'Lake House'); Irida Lankadeepa and Lankadeepa are published by Wijaya Newspapers Ltd, one of the largest news publishing companies in Sri Lanka. At the time of analysis, the two privately-owned newspapers had higher and wider rates of circulation than state newspapers. Daily and Sunday newspapers were chosen from each sector.

After an initial survey of items in January 2012, the study focused on the second week of the month, because it had the highest number of items in print in Sinhala (and English) newspapers for the month, due to the simultaneity of major events as described in the previous section. From a total of 176 items published during the month in these four Sinhala newspapers, 38 were published during this week (distribution shown in Table 1). This particular week, therefore, shows the general discourse trends of the Sinhala press towards undergraduates and state universities in a more marked manner.

Table 1: Number of items in print media, $11^{\text {th }}-13^{\text {th }}$ and $15^{\text {th }}$ January 2012

\begin{tabular}{|l|l|l|}
\hline Ownership & Newspaper & No. of items \\
\hline \multirow{3}{*}{ State } & Silumina $(S)$ & 02 \\
\cline { 2 - 3 } & Dinamina $(W)$ & 08 \\
\hline \multirow{2}{*}{ Private } & Irida Lankadeepa & 07 \\
\cline { 2 - 3 } & Lankadeepa & 21 \\
\hline Total & & $\mathbf{3 8}$ \\
\hline
\end{tabular}

The 38 items analysed here are genre specific: editorials, feature articles and news reports. Interviews, letters and press releases were excluded from the analysis. Interviews were excluded because the content of the interview is not produced by the newspaper. For instance, a newspaper may publish interviews from two people with opinions that diverge, conveying the newspapers' desire to give space to different perspectives; while the decision to publish the interview (and whether to 
publish in its entirety) is the editorial board's decision, the content of the interview is outside the newspaper agency's purview. Likewise, letters to the editors and press releases are written by outsiders to the news agency, even though their publication conveys editorial approval. Editorials, news reports, and feature articles, on the other hand, include planned content produced by the news agency's staff, mostly under the direction of the editorial board itself. We can assume then that these genres are more representative of the discourse of each newspaper or agency.

In the following sections of the paper, I first present an analysis of the state-owned newspaper's representation of undergraduates, followed by that of the privatelyowned newspapers' representation. A third section details the Sinhala language features that are used to show stance and focus in the Sinhala press. News excerpts are presented in two columns. The first column presents the Sinhala excerpt transliterated in the Roman alphabet. Two phonetic symbols are used: /æ/ for the open front unrounded vowel sound (e.g. vowel sound in can); /2/ for the midcentral unstressed vowel sound (e.g. vowel sound in her). A colon indicates a long vowel sound (e.g. /ræ:n/ for ran). The second column presents a near-literal translation in English, i.e. some pragmatic content may be lost. For the purposes of this paper, references to 'media' should be read as references to print media.

\section{Print Media Representation: Findings and Discussion}

\section{Undergraduates in State-Owned Media}

State-owned Sinhala newspapers, Silumina and Dinamina, gave markedly less coverage to university issues in comparison to their privately-owned counterparts, producing 10 out of the total 38 items. These 10 items, however, included editorials, high in impact given their role as the opinion of the editorial board. Notably, all three editorials functioned as warnings or harbingers of evil tidings, signalling this with the use of metaphors in their titles: "the cat's paw of a sacrifice" ("Bilipu:ja:wəkə balal athə" 2012), "The university bedevilled" ("Sarəsaviyətə bahirəvəya: eyi" 2012) and "Saturn in the university" ("Sarəsaviye: henəhura!" 2012). The metaphor used in the first two titles, that of a treasure guarded by a malevolent being ("bahirəvəya") who can only be 
appeased by a live sacrifice ("bilipu:ja:wə”), i.e., the students, is a productive metaphor for the Sinhala newspapers analysed. Referencing undergraduates as both the sacrifice and the devil is illustrative of the double-faced portrayal that characterises state-affiliated news discourses on undergraduates: on the one hand they are innocent students sacrificed to the agendas of powerful third parties, and on the other, they are violent students who wreck the university system. This latter form of typecasting is evident in the third editorial title as "the astrologically malefic Saturn' (henəhura:). By indexing folk cultural beliefs carrying forceful negativity in their titles, newspapers depict universities as an uncertain space, helpless against other more powerful forces.

Lawlessness in universities, implied in the titles of the editorials, is a recurrent theme in state newspapers. University closures are dealt with in detail, using discursive strategies such as imperatives and justifying authoritarian interventions. Dinamina reports that Vice Chancellors of the universities had difficulty 'controlling' (“pa:lənəyə”) undergraduates and asked for 'interventions' ("mædihathwi:m") from parents and the government (Priyashanthi 2012b). The image of universities as unrestrained and violent spaces is heightened by frequent reports on ragging and student protests. The editorials of Dinamina and Silumina explicitly address the closure of universities, stating that these closures are necessary measures due to the 'troublesome' ("kalahaka:ri:") politics of Janatha Vimukthi Peramuna (JVP) (“Sarəsaviye: henəhura!” 2012); also ("Sarəsaviyətə bahirəvəya: eyi" 2012). By framing undergraduates as 'uncontrollable' and intervention as necessary, parents and Vice Chancellors are produced as the moral and institutional authorities suited for such an intervention. It implies that strong measures taken against students, and a discourse on undergraduates as a 'problem' is acceptable.

The reference to the JVP, an organisation long associated with student unions, is used in the construction of the dichotomous undergraduate profile. According to these news reports, while some 'extremist' students ("antəwa:di:", Priyashanthi 2012 b) create trouble, the majority of the students are 'preyed on' by 'bankrupt political parties’ (“bankoloth de:shəpa:lə:nə pakshə”, Priyashanthi 2012b). The 
state newspapers cite not only the JVP but also the Liberation Tigers of Tamil Eelam (LTTE) as key elements in student politics, naming them 'puppet masters' (“ru:kədə natəwanna:”, “Bilipu:ja:wəkə balal athə” 2012, Priyashanthi 2012b). The mention of two political parties associated with war and violent insurrections serves to advance the image of lawless students. At the same time, it contributes to the rendering of the undergraduate as hapless and passive victims, reinforcing the necessity for authoritarian intervention by the state and university administration.

Another thematic strand in these newspapers is the need for globally relevant knowledge, which is then shown to be lacking in Sri Lankan universities. Given here is an excerpt from Dinamina:

\section{Excerpt 1}

\begin{tabular}{|c|c|}
\hline & \\
\hline 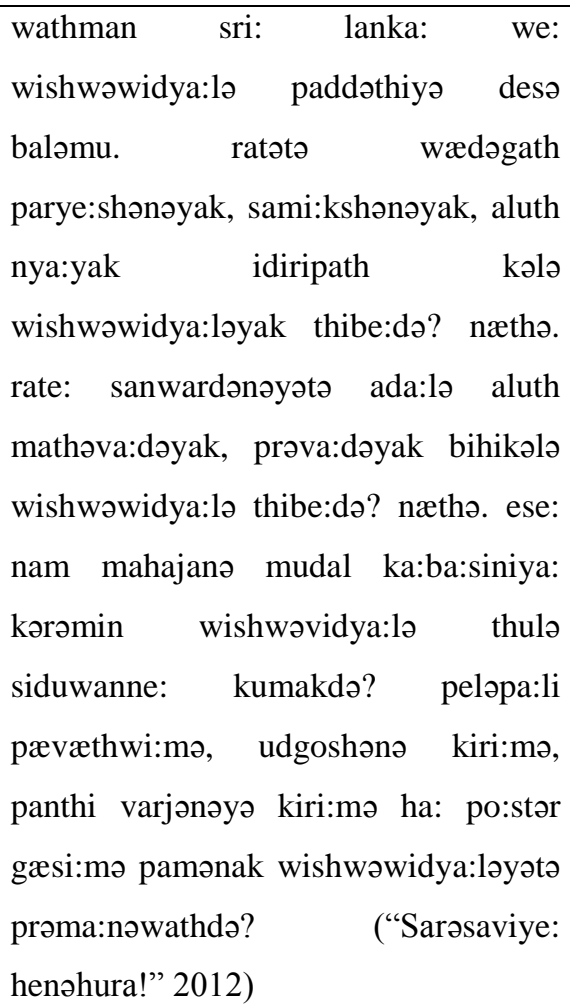 & $\begin{array}{l}\text { Let [us] look at the university } \\
\text { system in present-day Sri Lanka. Is } \\
\text { there a university that has presented } \\
\text { an important study, survey, or a new } \\
\text { theory important to the country? } \\
\text { No. is there a university that has } \\
\text { produced a new perspective, } \\
\text { theorem relevant to the development } \\
\text { of the country? No. If that is so, what } \\
\text { happens in the universities [that are] } \\
\text { eating up public funds? Is it enough } \\
\text { for the university solely to go on } \\
\text { protest marches, strikes, and poster } \\
\text { campaigns? }\end{array}$ \\
\hline
\end{tabular}


The excerpt shows the news item purportedly evaluating the current status of universities. It begins with an exhortatory directive 'let's look,' (“baləmu”) inviting the reader, i.e. the public, to consider the function of universities together. Through this the reader becomes complicit in judging universities as failed institutions, unable to produce globally applicable knowledge. The structure of the argument is a series of rhetorical questions with emphatic negatives leading the reader towards the final rhetorical question 'Is it enough for the university solely to go on protests marches, strikes, and poster campaigns?' The reference to 'public funds' reminds the public that funds that should rightfully be used for knowledge production are misused for protest campaigns. The references to England and Malaysia are then placed as foils to Sri Lankan universities, emphasising the lack of knowledge production in the country. With the use of such linguistic strategies, the editorial builds an affective stance against the university community.

These references to global knowledge economy serve to reinforce the government's discourse on higher education at the time (Mahinda Chintana n.d.). In the excerpt shown below, from a Dinamina editorial, university closures are once again brought up as a necessary evil but this time, they are also linked to a particular type of knowledge production:

\section{Excerpt 2}

\begin{tabular}{|l|l|l|}
\hline \multicolumn{2}{|c|}{ Excerpt Transliterated } & \multicolumn{2}{c|}{ Translation } \\
\hline wishwəwidya:lə wasa: damannətə sidu & Why does it become necessary to \\
wanne: æyi? i:tə diya hæki keti & close the universities? The short \\
pilithurə wanne: ja.vi.pe. & answer that can be given to that is: \\
de:shəpa:lənəyə wisin æthi kərənu & these institutions have to be closed \\
labənə kalahaka:ri: thaththvəyə nisa & due to the troublesome situation \\
me: a:yəthənə wasa: dæmi:mətə & created by JVP politics... one of \\
siduwənə bavəyə....owunge: prəda:nə & their main ideas is that the capitalist \\
adəhasak wanne: danəpəthi adya:pənə & education system should be rejected. \\
krəməyə prəthikshe:pə kələ yuthu & By rejecting capitalist education, no \\
bavəyə. danəpəthi adya:pənəyə & developed science will be learned. \\
prəthikshe:pə kiri:men kisidu diyunu &
\end{tabular}


vidyawak igeni:mətə nohæki wənu

æthə. ("Sarəsaviye: henəhura!" 2012)

The reference to capitalist education, while seemingly contradictory to the then government's stance against Western countries, illustrates well the neoliberal shift in national educational policies with its focus on science and technology. In some convoluted manner, the repudiation of capitalism (and by implication 'developed science') by the JVP, has become the reason for university closures. This discourse on the need for 'capitalist education' also resonates with donor agency discourses (e.g. Asian Development Bank and World Bank) with their emphasis on the dire need for training in technical and vocational education for the country. However, on the Private Universities Bill itself, which had been widely called a state move against free education, the state newspapers report rarely. Both Dinamina and Silumina carry few items on it, denying the existence of such a Bill while reporting extensively on violence in universities and university closures as a result of this. This is a significant silence, given their emphasis on educational issues. It also parallels the then government's own process of silence, repudiation and later withdrawal of their intention to bring the Bill to Parliament.

State newspapers (through both text and title) portray university students as pawns of a political power struggle at national level. By citing the LTTE and JVP, they evoke unpleasant connections in the readers' minds, implying the potential for future violence. The image of the student as victim is heightened with the use of paternalistic terms such as 'children' (“daruwan", "lamai") in quotes by government and university officials (Priyashanthi 2012a, 2012b). The infantalisation of adult undergraduates thus boosts the rationale for the use of force against them, as subjects of either bills or police and military disciplinary action.

By writing less (10 out of 38 items) on universities, state newspapers may have reduced visibility on this issue; yet, their decision to discuss these issues in editorials - an important subgenre in news - as well as the discursive strategies used in the reporting, illustrates that the issue is one of grave concern. 


\section{Undergraduates in Privately-Owned Media}

The Irida Lankadeepa, published on Sundays, and its daily Lankadeepa are privately-owned national newspapers and account for 28 of the 38 items published during this week. The two Lankadeepa newspapers provide detailed coverage of events in the universities during this time period. A reason for the higher number of units, however, is their strategy of reporting multiple events in universities separately, i.e., as discrete units, rather than synthesised accounts. For instance, in one issue of the Sunday newspaper Irida Lankadeepa (11 $1^{\text {th }}$ January 2012, p.14), one page published no less than six separate news items on university-related events that had taken place during that week. Its editorial focused on universities, while feature articles and news reports discussed protests by undergraduates and the bomb attack on the University of Sri Jayewardenepura. Its regular political feature section also discussed universities during this week. This 'discrete units' strategy facilitated the readers' focus on distinct issues or events, whereas a synthesised account may have merged these different issues into a nebulous 'university crisis' category. However, we could question whether the number of separate items on universities would contribute to the perception of universities as strife-laden institutions. In a sense, having discrete items highlights newsworthiness in terms of 'superlativeness', i.e., the more news on an issue, the more newsworthy it is (Bednarek and Caple, 2014).

The two privately-owned newspapers foreground student issues rather than academic or administrative concerns. This means, they foreground undergraduate protests, their clashes with the police, and student suspensions by university authorities. The front page of the daily Lankadeepa on $12^{\text {th }}$ January 2012, for instance, highlighted student protests by publishing several photographs of them in the centre of the page. The government's withdrawal of the controversial Private Universities Bill was published on the same page in small type. Such visual representation draws constant attention to student activities, the message to the reader being that student concerns are a more important issue for the general public. Here again, the newspaper's alignment with the student perspective 
conflicts with the newsworthiness of the story, signalled in their desire to highlight the protest through centrally placed visuals.

Textually, however, student voices are presented more frequently than university authorities or the government, especially in the daily Lankadeepa. The newspapers use quotes from student union representatives; and in many instances give wider coverage to them than to university administration. One article on a student strike (Kasthuri \& Kumara 2012), for example, focused mostly on the reasons for the strike and student perspectives on it, with minimal attention ( 2 of 7 paragraphs) to perspectives of university officials. The Lankadeepa also reports on press conferences held by students that are largely unreported by other newspapers. Added to these, larger fonts for headlines, central placement of headlines, and centrally placed visuals make the undergraduates the most important actor in Lankadeepa's reporting of universities.

The positioning of university students as the major issue is mirrored by the discursive strategies used by both newspapers through the device of focalisation, as shown in the excerpts below:

\section{Excerpts 3-5}

\begin{tabular}{|c|c|}
\hline $\mathbf{E x c}$ & \\
\hline $\begin{array}{l}\text { (3) ...owunge: siyəlu adya:pənə } \\
\text { katəyuthu soya: bæluwe: jye:shtə } \\
\text { shishyə kanda:yəmai (Samarathunga et } \\
\text { al, 2012, p.6) }\end{array}$ & $\begin{array}{l}\text { It was the senior student group that } \\
\text { looked after all their [the incoming } \\
\text { students'] academic issues }\end{array}$ \\
\hline $\begin{array}{l}\text { (4) me: awastha:we: sisun sahaka:rə } \\
\text { police adika:ri:wərəya: hamuwe: kiya: } \\
\text { sitiye: thamantə muhunə pæ:mətə } \\
\text { siduwi: thibenə adya:pənə gætəlu } \\
\text { sambandəyen } \\
\text { kiri:mətəwath upəkuləpəthiwərəya: } \\
\text { awastha:wak nodenə nisa: mewani } \\
\text { arəgələwələtə kæemoeththen ho: }\end{array}$ & $\begin{array}{l}\text { In this instance what the students } \\
\text { have told the police sub-inspector } \\
\text { was that because the vice chancellor } \\
\text { doesn't give them an opportunity to } \\
\text { even discuss their educational } \\
\text { problems, they have had to resort to } \\
\text { protests such as these whether they } \\
\text { like it or not. }\end{array}$ \\
\hline
\end{tabular}




\begin{tabular}{|c|c|}
\hline $\begin{array}{l}\text { akomoeththen ho: yomuwi:mato } \\
\text { thamanto siduwi: athi } \\
\text { bawayi. (Bandara \& Chandradasa 2012, } \\
\text { p.14) }\end{array}$ & \\
\hline $\begin{array}{l}\text { (5) Eda: meda: thurə danna: nodanna: } \\
\text { boho: piris tharunə sarəsavi sisuhu } \\
\text { thamange: ji:withə podu arəmunu } \\
\text { wenuwen pu:ja: kərə æthə. [...] } \\
\text { pa:ləkəyan kiyanne: kada: bində dama: } \\
\text { æththe: gadol-simenthi godak bawayi. } \\
\text { Pilimə kada: - prəthiru: bindədama: an } \\
\text { mathə yatəpath kələhækiyæyi api } \\
\text { kisiwitəkath nosithəmu. (Dasanayaka } \\
\text { 2012, p.38) }\end{array}$ & $\begin{array}{l}\text { From then to now, many young } \\
\text { people, known and unknown } \\
\text { undergraduates, have sacrificed } \\
\text { their lives to the common cause. } \\
{[\ldots] \text { Those who govern say that }} \\
\text { what is destroyed is a pile of bricks } \\
\text { and cement. We do not believe ever } \\
\text { that by breaking statues and } \\
\text { destroying images alternative } \\
\text { viewpoints can be suppressed. }\end{array}$ \\
\hline
\end{tabular}

These excerpts illustrate a more sympathetic portrayal of undergraduates in comparison to that of state newspapers, achieved with the inclusion of information and discursive features not used on behalf of undergraduates in state newspapers. These newspapers provide reasons for student protests, in excerpt 4 for example, which is not always provided or highlighted in state-owned newspapers. Indeed, in excerpt 5, the article explicitly supports the students' position. In direct contrast to the information in state-newspapers at the time, Lankadeepa papers also state that (according to undergraduates) senior students provide help to first year students, and that the university administration is not attentive to student needs. A rare instance of the private newspapers' incorporation of the university administration's perspective is shown in excerpt 6 below, from a Lankadeepa editorial: 


\section{Excerpt 6}

\begin{tabular}{|c|c|}
\hline Excerpt Transliterated & n \\
\hline $\begin{array}{l}\text { E: deparshwəyə namyəshi:li: wi:mə } \\
\text { pamənak nowə wishwəwidya:lə } \\
\text { arbudə wələtə wenath he:thudə } \\
\text { næththe: nowe:. De:shəpa:lənə ha: } \\
\text { wenath ba:hirə baləpæ:mdə memə } \\
\text { arbudə pasupasə æthi bawə rahasak } \\
\text { nowe:. Eheyin me:wa:tə he:thuwənə } \\
\text { abyanthərə ha: ba:hirə siyəlu sa:dəkə } \\
\text { gæmburin soya: } \\
\text { krəməwe:dəyəkə awashyətha:wədə } \\
\text { dæn pennum kærei. (“Ja’purə } \\
\text { kuləpəthi ma:himi adəhasath sæməge: } \\
\text { sæləkillətə lakwe:wa:” 2012, p.4) }\end{array}$ & $\begin{array}{l}\text { It is not that there aren't other reasons } \\
\text { for university problems, (in addition } \\
\text { to the issue of) flexibility of these two } \\
\text { parties [students and the } \\
\text { administration]. It is not a secret that } \\
\text { there are political and other external } \\
\text { influences behind these problems. } \\
\text { Therefore, a need is now shown for an } \\
\text { inquiry }{ }^{8} \text { that does an in-depth } \\
\text { investigation of all internal and } \\
\text { external causes of these (problems). }\end{array}$ \\
\hline
\end{tabular}

The editorial excerpt above draws attention to the multiple forces at play in undergraduate politics. While it appears to be a balanced discussion of different perspectives, with its comment on inflexible student groups and university administration, the subtext of the editorial is the involvement of external political parties in student politics. With the use of negatives ("nowe:") and double negatives (“næththe: nowe:") the reader's attention is pushed towards unnamed external forces, implying that this is widely known information ('not a secret') Even though the editorial asks for an inquiry on problems faced by the universities, the use of the involitive aspect of verbs (e.g. pennum kærei or 'is shown') dilutes the force of the demand. The editorial appears to be supporting the students without explicitly critiquing the government.

As can be seen from this section, the Lankadeepa newspapers' written discourse portrays student issues positively. They provide detailed accounts of the

\footnotetext{
${ }^{1}$ The literal English translation of "krəməwe:dəyə" is 'methodology', an unusual choice for this sentence.
} 
progression of university protests, stressing the peaceful dispersal by students or the use of tear gas by police and armed forces at peaceful student marches (Samarathunga et al 2012, p.6; Tennakoon 2012, p.3). These accounts counter the public image of university students as violent and uncontrolled/uncontrollable agitators. Unlike state-controlled newspapers, privately-owned newspapers critique the government by pointing to the unwarranted use of armed forces or police personnel or other action by university authorities against students.

This sympathetic portrayal is nevertheless undermined by the newspapers' visual impact. In many instances the newspapers use photographs of student marches, occupied spaces or iconic landmarks. Most images show students in action poses that can be construed as aggressive (or at the very least, agentive) whereas police personnel are usually shown in static poses: students marching en masse, with raised fists and open mouths indicative of shouting vs the police or the army standing in lines facing students. In addition, the titles of feature articles are either dramatically metaphorical (e.g. 'university afire'), or refer to student suspensions, protests or demands. The headlines and photographs, therefore, create a first impression of the university as a troubled and violent space, detracting from the content of the items and generating textual ambiguity. Student issues are still sensationalised, reinforcing existing stereotypes of students in state universities. This divergence illustrates the tension between the mainly sympathetic position of the news agency towards students and the tendency of the press to sensationalise an issue which is newsworthy. Despite the more detailed and nuanced presentation of the troubles within universities, privately-owned universities too, contribute to the sustained image of university students as trouble-makers.

\section{Linguistic structures in Sinhala media discourse}

Several linguistic features have been used by the Sinhala press for focus and stance-taking. These linguistic features are common to all the newspapers, though they have been used to different extents. These features are described below with examples. 
One of the most productive strategies, common in general to media discourses, is the use of flamboyant metaphors (Fairclough, 1995). As discussed in the previous sections, this is found in the Sinhala press as well. Examples of the metaphors used are 'cat’s paw' (balal athə), live sacrifices (bilipu:ja:wə), ‘abyss' (aga:dəyə), heat up (unusum viyə), old scripts (pærəni pitəpat) (see “Bilipu:ja:wəkə balal athə” 2012; Priyashanthi 2012a; "Sisu arəgələwələtə wisəndumə wanne: a:rthikəyətə gæləpenə adya:pənə krəməyəki” 2012 ; “Sisu kaləbələ pitupasə balal athak” 2012; Ranajana 2012; Tennakoon 2012; Tennakoon \& Kasthuri 2012). As Lakoff and Johnson (2008) have shown, the categories of the metaphors we use are important as a way of both highlighting and hiding aspects of our experience. In this case, the most salient categories appear to be that of victimhood (e.g. 'puppets,' 'live sacrifices,' 'offering lives'), prey ('carry off prey,' 'hooking fish,' 'cat's paw') and disasters ('arson,' 'abyss,' 'flames'). Of these, the metaphor of 'a cat's paw,' is of note since its usage in the Sinhala press is different to its meaning in English. In the Sinhala press, it is used to mean not only 'a person used unwittingly for another's purpose' as its meaning in English is generally given, but also as an instrument used by an agent. Two titles of articles will serve as examples of this: in 'the cat's paw of a live sacrifice,' the cat's paw is the undergraduate who is a victim (“Bilipu:ja:wəkə balal athə” 2012); whereas, in “An LTTE cat's paw behind student protests' (“Sarəsavi arəgələ pitupasə LTTE balal athak”), the term stands for the invisible hand of the LTTE that is instigating student unrest (Priyashanthi, 2012a).

A second linguistic strategy is the use of cleft sentences and assertion markers in Sinhala. The flexible syntactic structure of Sinhala allows us to move the clause that contains the main focus of a sentence to the end of the sentence. This latter part, the cleft (or focused) clause also contains assertion (or focus) markers $-y i$ (e.g. bawayi) and -ni (e.g. "washəyeni") which signals to the reader the authorial intent to focus meaning. In the sentence from excerpt 3, for instance, "It was the senior student group that looked after all their (i.e., the incoming students') academic issues" (owunge: siyəlu adya:pənə katəyuthu soya: bæluwe: jye:shtə shishy kanda:yəmai) the senior students are made prominent by its placement at 
the end of the Sinhala sentence and the assertion marker -yi (Samarathunga et al 2012, p.6). In the privately-owned newspapers these are used to enhance the voice of undergraduates (supporting the incoming students, trying to discuss their issues with authorities) conveying the message that protests are a result of unmet student needs. Through these, state action against students, such as arrests and police violence, is implied to be unsympathetic and unwarranted.

Two other linguistic structures are pervasive, that of double negation and subject deletion. One of these is the marked structure, double negation, which allows the author to make an affirmative statement but reduce its strength because the two negations cancel each other out. For example, see the sentence given below from excerpt 6 (“Ja'purə kuləpəthi ma:himi...” 2012, p.4):

E: deparshwəyə namyəshi:li: wi:mə pamənak nowə wishwəwidya:lə arbudə wələtə wenath he:thudə naththe: nowe: (emphasis added).

[It is not that there aren ' $t$ other reasons for university problems, (in addition to the issue of) flexibility of these two parties (i.e., students and the administration)]

By using the double negation "næththe: nowe:" the writer signals that the inflexibility of the two parties involved is the most significant problem even though other issues exist. However, the double negative is a marked syntactic structure, and draws attention to the author's knowledge of other issues as well.

Subject deletion is apparent in the texts of all four newspapers. Dropping the subject is a known phenomenon in Sinhala speech, which allows much syntactic flexibility (Gair and Paolillo, 1997). From the data analysed for this paper, it is evident that written Sinhala too allows the deletion of a subject from sentences. An example from excerpt 2 is 'by rejecting capitalist education [subject] will not be able to learn any developed science' (danəpəthi adya:pənəyə prəthikshe:pə kiri:men kisidu diyunu vidyawak igeni:mətə nohæki wənu æthə, "Sarəsaviye: henəhura!” 2012). In this sentence, deletion of the subject (which could have been 'you, students, the country') allows the avoidance of explicit stance taking for or against a group, and at the same time, provides for flexibility in reader interpretation. These linguistic devices are particularly salient in editorials, which 
is a genre that entails more stance-taking than in news reports, which would necessitate a more explicit statement of agentive action in its reporting.

\section{Conclusion}

This paper presented an analysis of the discursive representation of Sri Lankan undergraduates in the Sinhala press. Focusing on an eventful week in January 2012 when newspapers reported on universities with an unusually high frequency, the paper presents the differences in the treatment of undergraduate politics between state-owned and privately-owned newspapers, using editorials, news reports, and feature articles. These differences in reporting include differences in the types of information presented, headlines, genre preferences and the amount of space dedicated to this issue. Privately-owned newspapers dedicate more space for university-related issues, and have a generally sympathetic stance towards undergraduates, as evidenced in their writing. Yet, as shown above, the message given by the visual language (headlines, pictures) echoes that of the state-owned newspapers. State-owned newspapers provide less space and the perspective of authoritative voices (e.g. university officials, government administration) rather than student voices. Additionally, the most significant aspect of their reporting is a discursive construction of the undergraduate as either a troublesome student or a hapless victim of more powerful forces.

Despite these differences, however, Sinhala newspapers utilise several languagespecific features in common: the shift of clauses for syntactic focus, omission of the subject, double negation, metaphoric titles and the use of idioms. While the study considered only some genres in Sinhala newspapers, it is possible that these forms of representation and the linguistic features are used for stance-taking in media discourse in general. More extensive and in-depth studies of the language used in Sinhala media would bring us a better understanding of Sinhala political discourse. Studies of Tamil media are also important, and would greatly enhance our understanding of characteristics of public discourse in the country, especially given the lack of coverage of North-Eastern student issues in the Sinhala press. 
The differences in the ideologies and discourses stemming from ownership-based Sinhala media are possibly due to the function of state-owned media. The week of the data considered here is embedded in an intensely and aggressively confrontational feud between the populations of state universities (faculty and students) and the Minister of Higher Education. As agents of the state, therefore, the state-owned newspapers may have presented state-dictated portrayals of undergraduate issues. This is, however, a disturbing implication as the simplistic and damaging discourse on undergraduates (and through that, universities) from the state perspective implies a lack of faith in state universities. Antagonistic discourses on undergraduates justify the lack of state investment in universities and the problems that universities face from the government of the time. Changes in state discourses on universities, therefore, would be a useful area of study, given current the problems in higher education.

This study also makes it evident that the 'university student' is still a major focus of public attention, regardless of other newsworthy events in universities, such as faculty trade union campaigns or national educational policy changes. The differences between news groups make comparative studies across media important. Are all privately-owned media as 'supportive' in their news reporting? Has the state media's discourse changed over the years? What would a comparison between Sinhala, Tamil and English media tell us about public discourses on undergraduates? These are questions that would enable more concrete conclusions on media representation. This is especially important as academics, administrators as well as the students themselves are consumers and producers of these discourses.

\section{References (Primary Sources):}

Bandara, A \& Chandradasa, R. (2012). "Rajəratə waidyə sisuhu adikərənə niyogəyen sathyagrahayə ath harithi" [Rajarata medical students stop satyagraha after court order], Lankadeepa, 11 January,p.14, http://epaper.lankadeepa.lk/ epaper /services/ OnlinePrintHandler.ashx?iss... 
“Bilipu:ja:wəkə balal athə” [The cat's paw of a sacrifice] (Editorial), (2012), Silumina, 15 January, http://www.silumina.lk/2012/01/15/_art.asp?fn=ae120115

Dasanayaka, P. (2012), “Wiru sisu prəthima:we: de:shəpa:lənəyə” [The politics of the student leader's statue], Irida Lankadeepa, 15 January, p.38 http://epaper.dailymirror.lk/epaper/services/OnlinePrintHandler.ashx?issue=483 720120115000...

“Ja'purə kuləpəthi ma:himi adəhasath sæməge: sæləkillətə lakwe:wa:” [May everyone consider the opinion of the Ja'Pura Venerable Chancellor too] (Editorial), (2012), Lankadeepa, 13 January, p.4, http://epaper.lankadeepa.lk/ epaper /services/Online PrintHandler. ashx?iss...

Kasthuri, R \& Kumara, L S (2012), “Kæləni sarəsavi sisuhu akandə panthi varjənəyəkə” [Kelaniya University students in a continuous strike], Lankadeepa, 11 January, p.14, http://epaper.lankadeepa.lk/epaper/services/Online Print Handler.ashx?iss...

Priyashanthi, S. (2012a), "Sarəsavi arəgələ pitupasə LTTE balal athak" [An LTTE cat's paw behind student protests], Dinamina, 11 January, http://www.dinamina.lk /2012/01/11/_art.asp?fn=n1201111

Priyashanthi, S. (2012b), "Shishyə udgo:shənə barəpathələ kriya:wəliyəkə a:rambəyak" [Student protests are a precursor to a terrible movement], Dinamina, 13 January, http://www.dinamina.lk/2012/01/13/_art.asp?fn=n1201139

Ranjana (2012), "Sarəsavi wələ thirəyə pitupasə" [behind the curtain of the university], Lankadeepa, 13 January, p.16, http://epaper.lankadeepa.lk/ epaper /services/ OnlinePrintHandler.ashx?iss...

Samarathunga, S, Jayaruk, K J \& Perera, L N (2012), “Ginigath sarəsaviyə” [University afire], Irida Lankadeepa, 15 January, p.6,http://epaper.dailymirror.lk /epaper/services/OnlinePrintHandler.ashx?issue $=483720120115000 \ldots$

"Sarəsaviye: henəhura" [Saturn in the university] (Editorial), (2012), Dinamina, 11 January, http://www.dinamina.lk/2012/01/11/_art.asp?fn=e120111 
“Sarəsaviyətə bahirəvəya: eyi” [The university bedevilled] (Editorial), (2012), Dinamina, 12 January, http://www.dinamina.lk/2012/01/13/_art.asp?fn=e120113

"Sisu kaləbələ pitupasə balal athak" [A cat's paw behind student unrest], (2012), Silumina, 15 January, http://www.silumina.lk/2012/01/15/_art.asp?fn=aa1201159 "Sisu arəgələwələtə wisəndumə wanne: a: rthikəyətə gæləpenə adya:pənə krəməyəki" [the solution to student protests is an economically suitable education], (2012), Irida Lankadeepa, 15 January,p.4, http://epaper.dailymirror.lk /epaper/services/Online PrintHandler.ashx?issue=483720120115000.

Tennakoon, P. S. (2012), "Sarəsavi awulə hewath le:wæki athi:thəyə aluthen kæni:mə" [The university problem aka excavating anew the bloodied past], Irida Lankadeepa, 15 January, p.3,http://epaper.dailymirror.lk/epaper/services/ OnlinePrintHandler.ashx ?issue $=483720120115000 \ldots$

Tennakoon, P. S. \& Kasthuri, R. (2012), "Shishyə udgo:shənə nisa: sarəsavi paddəthiyə bindəwætila" [university system has disintegrated due to student protests] 2012 , Irida Lankadeepa, 15 January,p.7,http://epaper.dailymirror.lk/ epaper/services/OnlinePrintHandler.ashx $?$ issue $=483720120115000 \ldots$

\section{References (Secondary Sources)}

Bednarek, M. and Caple, H. (2014) 'Why do news values matter? Towards a new methodological framework for analysing news discourse in Critical Discourse Analysis and beyond', Discourse \& Society, 25(2), pp. 135-158. Available at: http://das.sagepub.com/content/early/2014/01/07/0957926513516041.abstract (Accessed: 28 September 2016).

'Chronicle' (1966) Minerva, 4(4), pp. 568-579. doi: 10.1007/BF02207988.

‘Chronicle' (1969) Minerva, 7(3), pp. 499-507. doi: 10.1007/BF01103274.

Dijk, T. A. Van (1988) 'Semantics of a press panic: The Tamil invasion', European Journal of Communication, 3, pp. 167-187. Available at: http://ejc.sagepub.com/content/3/2/167.short (Accessed: 11 September 2015).

Dijk, T. Van (1991) Racism and the Press. New York \& London: Routledge. 
Fairclough, N. (1995) Media Discourse. London: Edwin Arnold.

Gair, J. W. and Paolillo, J. C. (1997) Sinhala. München \& Newcastle: LINCOM EUROPA.

Lakoff, G. and Johnson, M. (2008) Metaphors we live by. Chicago \& London: University of Chicago.

Pieris, R. (1964) 'Universities, politics and public opinion in Ceylon', Minerva, 2(4), pp. 435-454. doi: 10.1007/BF01097537.

Richardson, J. E. (2007) Analysing newspapers: An approach from critical discourse analysis. New York: Palgrave Macmillan.

Samaranayake, G. (1992) 'Changing Patterns of Student Politics in Sri Lanka: A Case-Study of the University of Peradeniya', in Gunawardane, R. A. L. H. (ed.) More open than usual? An assessment of the experiment in university education at Peradeniya and its antecedents. Peradeniya: University of Peradeniya, pp. 101113.

Samaranayake, G. (1997) 'Political Violence in Sri Lanka: A Diagnostic Approach', Terrorism and Political Violence, 9(2), pp. 99-119. doi: 10.1080/09546559708427405.

Samaranayake, G. (1999) 'Patterns of political violence and responses of the government in Sri Lanka, 1971-1996', Terrorism and Political Violence, 11(1), pp. 110-122. Available at: http://www.tandfonline.com/ doi/abs/10.1080/09546559908427497 (Accessed: 28 November 2014).

Samaranayake, G. (2015) 'Changing University Student Politics in Sri Lanka : From Norm Oriented to Value Orient Student Movement', Social Affairs: A Journal for the Social Sciences, 1(3), pp. 23-32.

Samaranayake, G. (2016) 'Expansion of university education, graduate unemployment and the knowledge hub in Sri Lanka', Social Affairs: A Journal for the Social Sciences, 1(4), pp. 15-32. Available at: http://socialaffairsjournal.com/ CurrentIssue/2.Expansion of University Education, Graduate Unemployment and the Knowledge Hub in Sri Lanka - Samaranayake.pdf (Accessed: 12 September 2016). 
Schubert, A. (2012) “"Thela Bedeema”: Examining the culture of student violence within a state university in Sri Lanka', Dialogue (NS), XXXIX, pp. 259-294.

Uswatte-Aratchi, G. (1974) 'University Admissions in Ceylon: Their Economic and Social Background and Employment Expectations', Modern Asian Studies, 18(3), pp. 289-318.

Uyangoda, J. (1989) 'The Politics of Sri Lanka in 1989', Comparative Studies of South Asia, Africa and the Middle East, 9(2), pp. 1-7. doi: 10.1215/07323867-9$2-1$.

Weeramunda, A. J. (2008) Report of the research study on 'The sociopolitical impact of student violence and indiscipline in universities and tertiary education institutes'. Colombo. Available at: http://nec.gov.lk/wpcontent/ uploads/2014/04/Socio_Political_impact_on_the_students_and_staff.pdf.

Wickramasinghe, N. (2005) University Space and Values: three essays. Colombo: International Center for Ethnic Studies.

Zubair, C. (2011) 'Ideologies of purity and corruption: The local impacts of Sinhalese nationalist discourse', in Kirk, G., Lopez, O., Sullivant, J.R. \& Wartel, M. (ed.) Proceedings of the Nineteenth Annual Symposium about Language and Society.

${ }^{1}$ During the month of January 2012, these newspapers published 176 items (of the same genres) in total; whereas, only 90 items were published during this month in four comparable English newspapers (Daily News, Sunday Observer, Sunday Times, Island). 